\title{
THE EFFECTS OF POLLUTION ON BENTHIC FAUNA IN BINDARE STREAM, ZARIA, NIGERIA.
}

\author{
J.A. Adakole*, J.K. Balogun and F.A. Lawal" \\ Department of Biological Sciences, Ahmadu Bello University, Zaria, Nigeria.
}

\begin{abstract}
Five sampling stations (four on bindare stream and one on River Galma) were monitored monthly for physical, chemical parameters and benthic population for a period of six months. Forty taxa, comprising a total of 3,218 individuals were collected. The classes Diptera (dominated by Chironomus spp and Cryptochironornus spp and Eristalis spp) and Oligochaetae (Lumbricul:s spp, Nais spp and Tubifex spp) were most abundant species contributing 81.14\% of the total invertebrates. The physico-chemical characteristics of the indusirial essate effluent and those of the streain were lower than the limits set by FEPA. However, dise preponderance of Diptera and Oligochaetse at mid-stream reflects an organically stressed acquatic environment.
\end{abstract}

\section{NTRODUCTION}

During the past two cecades, considerable interest in ezvironmental degradation has focused on the ecologv of streams and wivas. Tie roie or ecologists in interpreting the effects of effluents and formulating appropriate management practices is severely restricted by inadequate measurement techniques and lack of fundamental data concerning the functioning ecosystem ${ }^{1}$. Traditionally, water quality status of streams is determined by direct physicochemical analysis of the water or bioassay ${ }^{2}$. The weakness of these methods is that result obtained only reflects the water quality at the time of sampling. Therefore, recent studies in water quality management have focused on the use of benthic fauna in assessing the impact of pollution on aquatic environments ${ }^{3-7}$. A detailed overview on selective advantage of benthic fauna in water quality assessment is given by Hella-well ${ }^{8}$. Pollutional status of streams and rivers determines which organisms can survive in them. Bindare stream, a major stream that drains Chikaji Industrial Estate, is also fed by urban run-offs and seepage from agricultural farmlands. The stream has two main uses which include agriculture (irrigation, fishing and watering of livestock) and domestic (washing and bathing). The present study provides preliminary information on the stream's physico-chemical characteristics and the possible impact of pollution on the abundance and distribution of benthic fauna in Bindare stream. The stream flows through farmlands and urban/industrial areas with varying human activities and water pollution sources.

* Author for correspondence

** Present address: National Research Institute for Chemical Technology, Kano, Nigeria

Nigerian Journal of Chemical Research, Vol 3, 1998

\section{EXPERIMENTAL}

Study Area

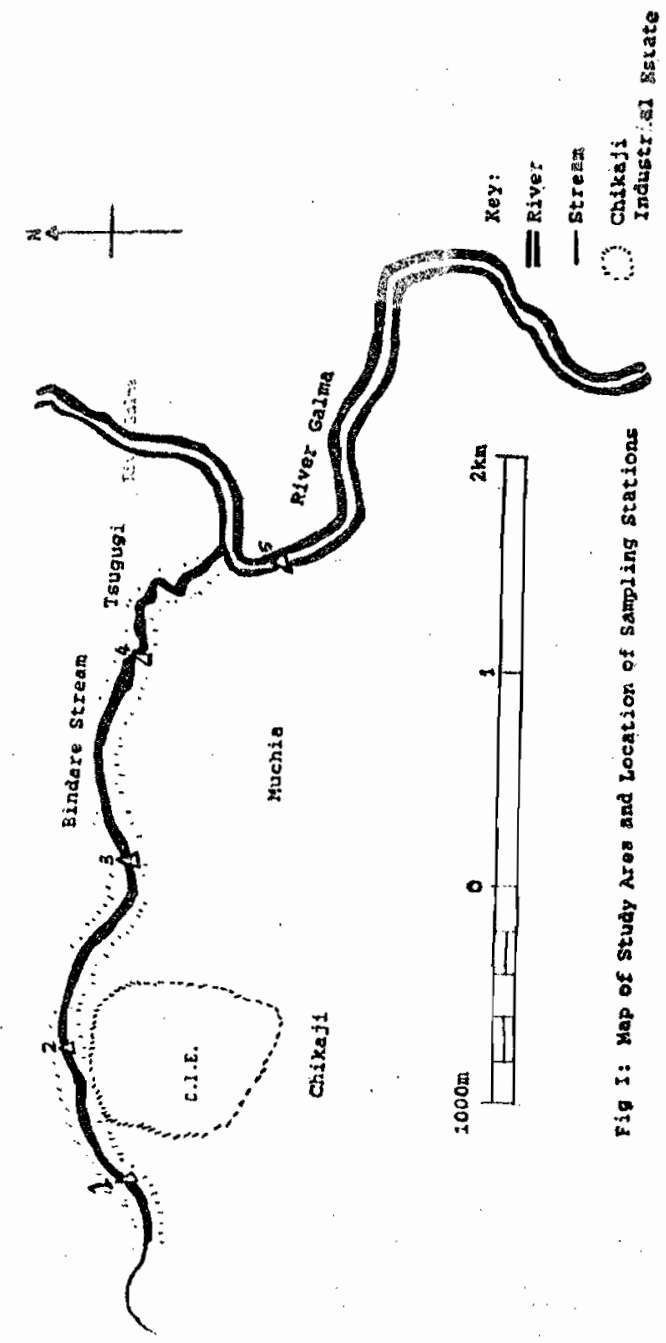


Bindare stream (F ig. 1) flows in a West-East direction along a gully situated to the east of Sabon gari and the Chikaji Industrial Area, Zaria. Most part of the gully contai is water throughout the year probably because it cuts through a perched water table. Also the guly receives various effluents. Bindare stream which is sbout $6 \mathrm{~km}$ long takes its source from Kwangila hills and empties into river Galma. The nature of Biıdare stream channel varies considerably both frcm station to station and from time to time. Attemr ts to conserve the stream water include construct on of earth/sand barrages and artificially enlarging and deepening of pools. Heaps of refuse, human faeces and cattle dung are found on the slopes of the valley. Municipal and Industrial effluents arc channelled into the same drains and subsequently into the stream irrespective of their quality.

Five sampling stitions were chosen on the stream for the study. Stition 1 is located upstream before Chikaji Industrial Estate. Station 2 is about $20 \mathrm{~m}$ after $B$ isure striam had received all the effluents from Chikaji Incustrial Estate, it is about $1.3 \mathrm{~km}$ from station 1. Station 3 (about $1.1 \mathrm{~km}$ from station 2) is located just after the stream had begun to receive domestic effluents. Station 4 (about $1.1 \mathrm{~km}$ from station 3) is located after the stream had received most of th 1 municipal effluents. Station 5 , located on river Galma, is $20 \mathrm{~m}$ after the stream had joined the river.

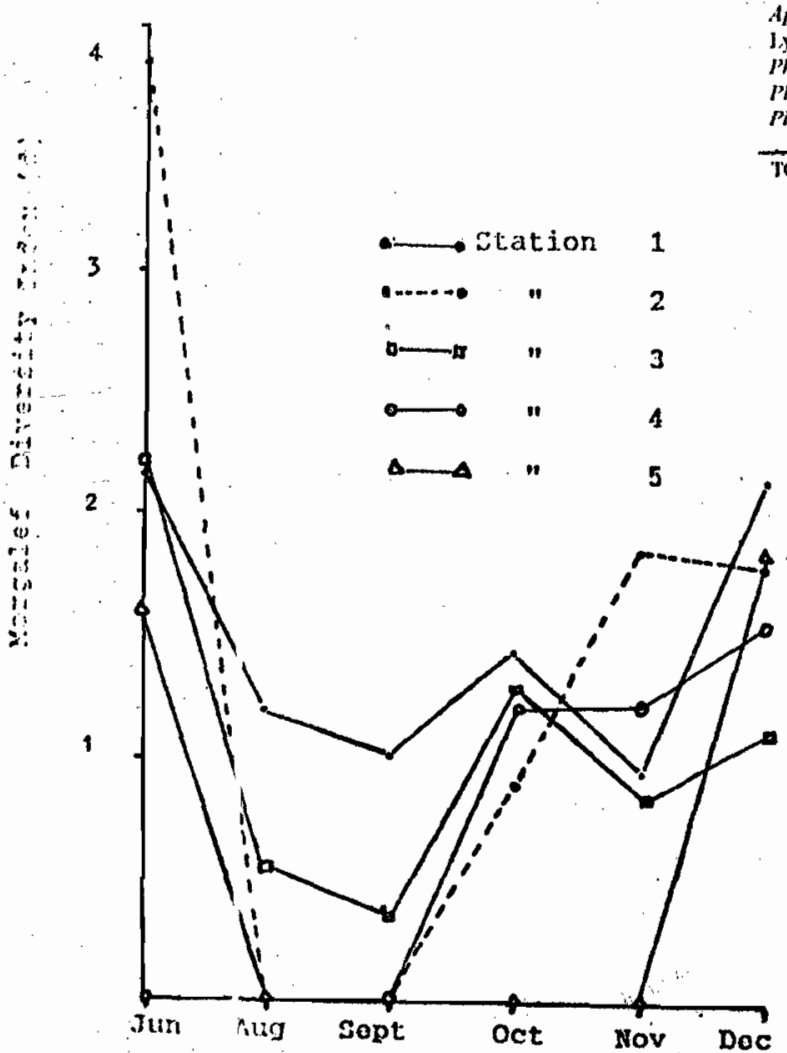

Fig. 2. The monthly variation in Margalef index (a) in the sampling stations.

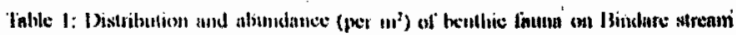

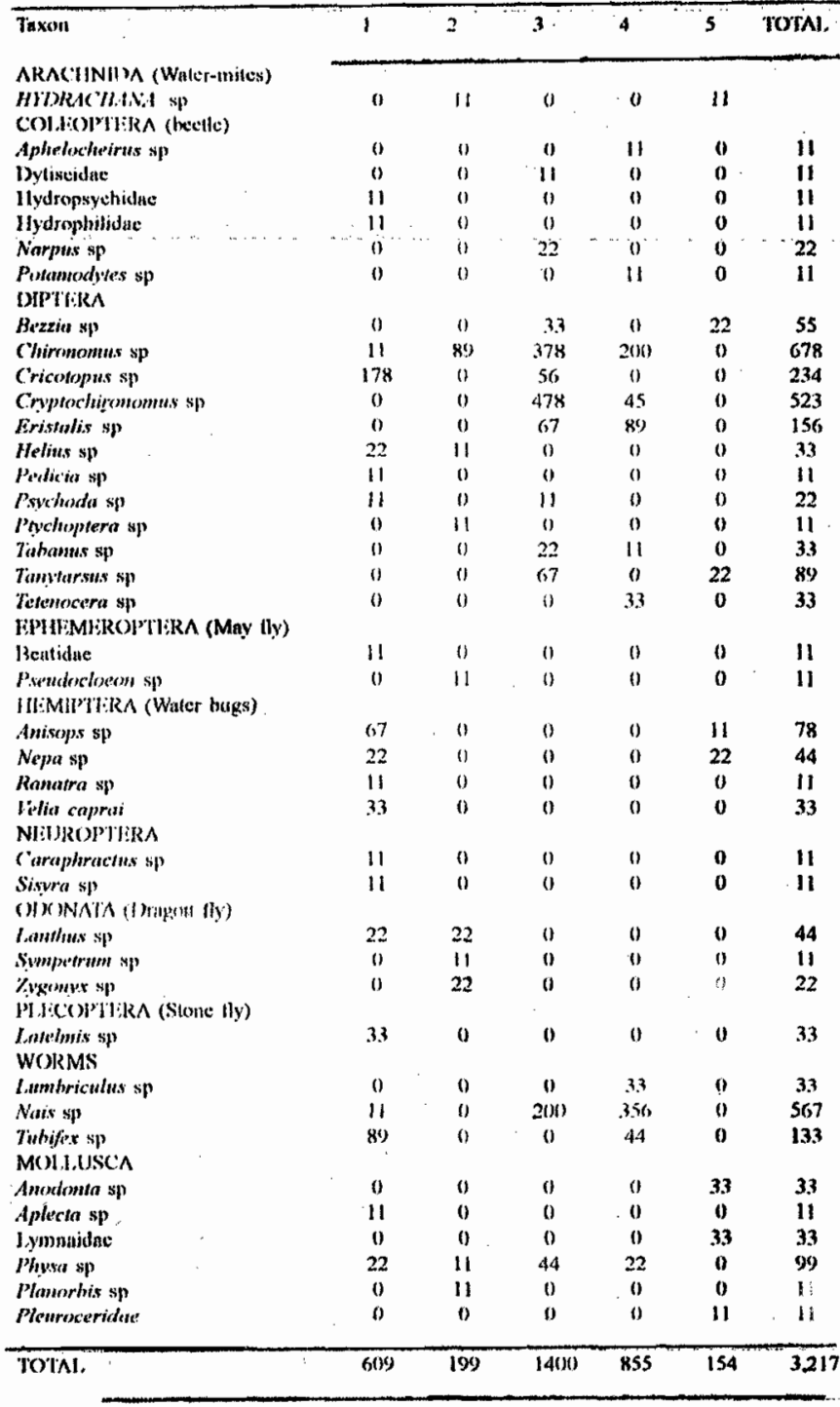

\section{Biological and physico-chemical characteristics}

Benthic fauna samples were taken monthly from June - December 1997 using Peterson drege with an opening of $0.09 \mathrm{~m}^{2}$ in accordance with APHA9. During each month, three random samples of the substratum were collected from a cross section of the river bed at each station. The substratum samples were washed through two separate sieves of mesh size $1.0 \mathrm{~mm}$ and $0.592 \mathrm{~mm}$ and the filtrate put into a polythene container with $4 \%$ formalin as preservative ${ }^{10}$. In the laboratory, animals counted were then expressed per square meter. After sorting and identification ${ }^{11-13}$, water quality for each station was determined using the diversity (d) indices of Margalef.

$$
\text { Margalef index, } d=S-1 / \log _{e} N
$$

Where, $\mathbf{S}=$ total number of species; $\mathbf{N}=$ total number of individuals in the sample. Results are as shown in Figure 2. 
Surface water and sediment samples were collected monthly from each station in the same vicinity where the substratum samples were collected. Effluent was also collected from the only functional Industry of the Industrial Estate as at the time of sampling. Analysis for physico-chemical parameters were done using standard methods as recommended $^{9.14}$. Results are shown in Table 2.

\section{RESULTS AND DISCUSSION}

The overall benthic fauna composition of Bindare stream and one station on river Galma included 40

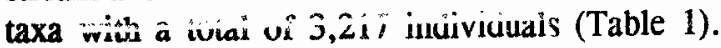
The number of taxa present in stations $1,2,3,4$ and 5 w:re $20,9,13,11$ and 7 respectively while the total umber of individuals collected th ioughout the stu ly period were $609,199,1400,855$ and $154 \mathrm{r}$ :spe:tively.

Class Diptera was the most abundant taxon represented by 12 genera. Chironomus spp, Cryptochironomus spp and Eristalis spp which constituted $72.26 \%$ of this class were essentially restricted to stations 3 and 4 . The Oligochaetae represented bv Lumbriculus spp, Nais spp and Tubifex spp were the second most abundant taxon. Inese too, were restricted to stations 3 and 4 . The tax Hemiptera, Ephemeroptera, Plecoptera, Odonar and Neuroptera were found exclusively at stations 1,2 and 5 . These orders are reported to be found in relatively clean environment ${ }^{1.7}$. The molluscs representing only $6.15 \%$ of the total catch were found in all stations. Margalef's water quality index values greater than 3.0 indicate clean conditions, values less than 1.0 indicate severe pollution and intermediate values indicate moderatc pollution ${ }^{2}$. The Margalef water quality index was generally below 2.0 in all the sampling stations during the period of heavy rain (August to October, Fig. 2).

Total dissolved solids, BOD and free $\mathrm{CO}_{2}$ which are indicators of organic pollution are moderately high based on classification ${ }^{15}$. Mean total water hardness among the sampling stations is in the order station $5<$ station $1<$ station $3<$ station $4<$ station 2, (Table 2). Mean alkalinity value was lowest at station $2\left(24.8 \mathrm{mgl}^{-1} \mathrm{CaCO}_{3}\right)$ and highest at station $4\left(17.7 \mathrm{mgl}^{-1} \mathrm{CaCO}_{3}\right)$.

Some of the effluent characteristics are $\mathrm{pH}$ (2.7), Electrical condúctivity $(7004 \mathrm{~S} / \mathrm{cm})$, Dissolved oxygen $\left(7.0 \mathrm{mgl}^{-1}\right)$, BOD $\left(12.5 \mathrm{mgl}^{-1}\right)$, Total alkalinity $\left(18.0 \mathrm{mgl}^{-1} \mathrm{CaCO}_{3}\right)$, Total hardness $\left(1892.0 \mathrm{mgl}^{-1}\right.$ $\mathrm{CaCO}_{3}$ ) and Total dissolved solids $(455.0 \mathrm{mg} / \mathrm{l})$.

Forty taxa were collected from all the five sampling stations. This compares fairly with over 55

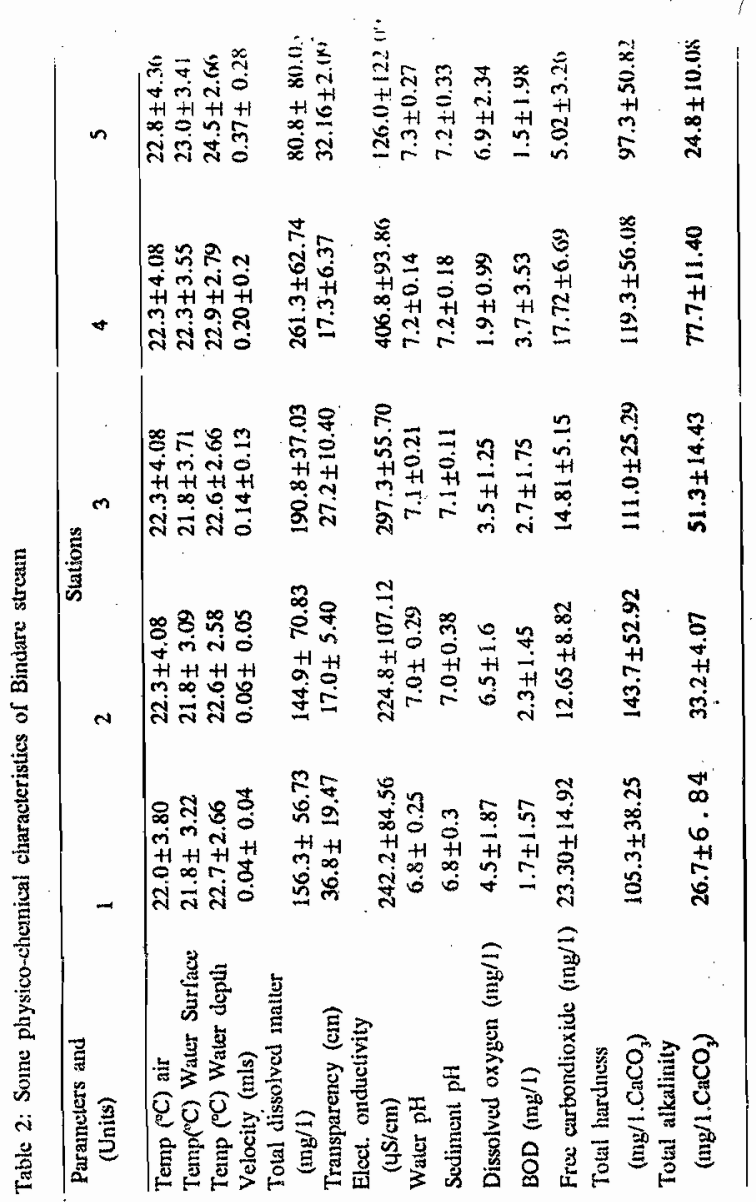

reported for tropical streams ${ }^{1,5,16}$. The contribution of the Industrial Estate effluent on the stream :eems to be only in terms of water har Iness. The

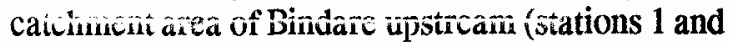
2) and the station on river Galma (station 5) are farmlands with few isolated human settlements suggesting a less polluted water environment, allowing the surival of even less tolerant species such as Ephemeroptera, Hemiptera, Plecoptera, Odonata and Neuroptera. The presence of Hirudinea, Hemiptera, Ephemeroptera, Plecoptera, Odonata and Gastropoda in aquatic ecosystems reflects the richness of such habitats and water cleanliness ${ }^{17,17}$.

The restriction of class Diptera and Oligochaetae to stations 3 and 4 could be attributed to the discharge of various effluents with characteristic properties into sections of the river which could have caused disruption of life cycle, reproductive cycle, food chain, migrations or imposed physiological stress on the less tolerant benthic fauna; hence the absence of benthic fauna associated with clean water quality. The tolerant species have overcome the above problems, adjusted to changes and carried out their life processes. Since the presence of Diptera and Oligochaetae in water bodies are indicative of organic pollution ${ }^{7.18}$, Stations 3 and 4 could be said to be organically polluted probably due to domestic sewage received by the stream at these stations. 
There was a positive correlation between total dissolved matter and electrical conductivity throughout the study peliod. The trend is in the order $4>3>1>2>5$. The higher total dissolved matter recorded in Station 1 compared to Station 2, despite the higher ej fluent received at Station 2 could be due to faster sedimentation rate of suspended materials like silt and clays at Station 1. Compared to other stitions, both Stations 3 and 4 recorded lower dissolved oxygen and higher BOD values probably (lue to domestic effluent received by the stream at these stations. During the study period, the least vilues of free carbon dioxide, BOD, total hardness, to al alkalinity, total dissolved matter and electrical ;onductivity were obtained at Station 5 suggesting a cleaner water condition of River Gaima compared to Bindare stream where the other four sampling stitions were located. These low values could be attributed to dilution and sparse settlement arouni Station 5. Similar observation was made on a Ugandan urban stream.

Temperature colrelated negatively with the dissolved oxygen in all the stations except at Stations 3 and 4 . Heating causes oxygen to volatilise out of solution.

The absence of phenolphthalein alkalinity in all the stations is indicative of the absence of normal bicarbonate and hydroxide ${ }^{14}$. For fish production, moderately hard waters with concentrations between $75-150 \mathrm{mgl}^{-1} \mathrm{CaCO}_{3}$ and 180 or above are preferred ${ }^{14}$. In this study, the mean values range between 97.33 (Stetion 5) and 143.7 (Station 2) $\mathrm{mgl}^{-1} \mathrm{CaCO}_{3}$. Bi sed on known standards of 61-120 and 180 and $\left.a b_{1}\right) e^{14,19}$, it will be logical to conclude that river (ialma and Bindare stream are moderately hard and very hard respectively and are rich enough with respect to water hardness to sustain fish prodution.

\section{CONCLUSION}

Total dissolved solids, BOD and free $\mathrm{CO}_{2}$ which are indicators of organic pollution were moderately high. The class Diptera and Oligochaetae were restricted to Sta:ions 3 and 4 . These stations could be said to be or ganically polluted probably due to domestic sewage received by the stream through them.

\section{REFERENCES}

1. Kizito, M.ls.C., M.Sc. Thesis, Makerere Uni versity, $19: 39$.
2. Lenat, O.T., Smock, L.A. and Penrose, O.L., in Douglass, L.W., (ed.), Biological Monitor ing for Environmental Effects, Lexington books, Toronto, 1980.

3. Dills, G. and Rogers, D.T., Environ. pollut., 1974, 6, 239.

4. Washington, H.G., Water Res., 1984, 18, 653.

5. Victor, R. and Ogbeibu, E.A., Environ. pollut. Ser.A., 1985, 39, 333.

6. Adakole, J.A., M.Sc. Thesis, Ahmadu Bello University, 1995.

7. Matagi, S.V., Arch. Hydrobiol., 1996, 137 (4), 537.

8. Hellawell, J.M., in Alabaster, J.B., (ed.), Bio logical Monitoring of Inland Fisheries, Applied Science Publisher Ltd., London, 1976.

9. A.P.H.A.-A.W.W.A.-W.P.C.F. American Public Health Association. Standard Methods for the Examination of Water and Wastewater, 16th ed., Washington D.C., 1985.

10. Margalef, R., Perspectives in Ecological Thoery, 3rd ed., Univ. Chicago Press, 1974.

11. Garnett, W.J., Freshwater Microscopy, Constable \& Co. Ltd., London, 1953.

12. Edmondson, T.W., Freshwater Biology, JohnWilly \& Sons INC., New York, 1959.

13. Needham, J.G. \& Needham, P.R., A guide to Study of Freshwater Biology, 4th ed., Holden-Day Inc., San Francisco, 1962.

14. Lind, O.T., A Handbook of Limnological Methods, C.V. Mosby Co:, St. Louis, 1979.

15. Vowels, P.D. and Connell, D.W., Experiments in Environmental Chemistry, Pergamon Press, New York, 1980.

16. Bishop, J.E., Monographic Biological, 1983, $22,118$.

17. Brooker, A. and Sweeting, R. In Gardiner, J.L., ed., River Project and Conservation, Joln Wiley and Sons, Chichester, 1991.

18. Hynes, H.B.N., The Ecology of Running Wa ters, Liverpool University Press, Liverpool, 1972.

19.Thurston, R.V., Russo, R.C. and Narmer, Y.M., Quality Criteria For Water, American Fisher ies Society, Banthesda, M.D. Publishers, New York, 1979.

accepted 17/3/99

received $11 / 1 / 99$ 